\title{
THE POLITICS OF THE POLISH PEASANT
}

The Polish Peasant Party celebrated its sixtieth anniversary last year. Founded in July 1895 in the provincial town of Lwow, its influence was at first confined to the parts of Poland then under Austrian rule. From modest beginnings, however, it eventually came to play a vital role in Polish politics. The important part taken by the peasant in Polish cultural life over the last half century has been largely the achievement of the political peasant movement. It was to give the reborn Polish state one of its greatest political leaders, Wincenty Witos, who three times held the office of Prime Minister between the two wars; and Witos's successor as leader of the Peasant Party was Mr Stanistaw Mikolajczyk, Prime Minister of the war-time Polish Government-in-Exile during some of the most crucial years in Polish history. Inflexibly opposed to the semi-authoritarian regime which ruled Poland during the 'thirties, the party likewise opposed the imposition of Communism on the country after the last war.

Before 1918 an organised political peasant movement had existed only in the southern part of Poland known as Galicia, which, as a result of the loss of national independence during the partitions of Poland in the second half of the eighteenth century, formed a province of the Austro-Hungarian Empire. In the parts of Poland under Prussia, though parliamentary institutions existed, class solidarity between Polish peasant and Polish landowner was strong, while the peasant was comparatively well-to-do and the landowner agriculturally progressive. The policy of Germanisation followed by the Prussian Government with increasing severity during the early years of the present century had tended here to bring the Poles together into a wellknit community. Under Russia, the third partitioning power, while class differences were sharp and clear-cut, the Tsarist autocracy excluded, except for a short period after the Russian revolution of 1905, any possibility of political activity among the peasantry who, even under favourable circumstances, are hard to organise politically. Only 
under Austria, therefore, where the Poles enjoyed a wide measure of autonomy and a liberal political regime, did the conditions exist for the emergence of the peasantry as a political force. In Austrian Galicia, moreover, the Polish peasants were uneducated, poverty-stricken and land hungry and without an outlet in industry within the country for their surplus population.

The first steps to awaken the Polish peasants politically were taken, as in many other peasant countries, by members of the intelligentsia. A Roman Catholic priest, Father Stojalowski, who, despite the fact that he based his political creed on the christian social doctrines of the papal encyclicals, was for long fiercely attacked by his clerical superiors as a revolutionary, and a young engineer, Boleslaw Wyslouch, who had imbibed agrarian socialist ideas, usually known under the name of populism (narodnichestvo), during his student years in St Petersburg in the'seventies, had both been active in Galicia from the I880's onwards.

Though important as a pioneer, Father Stojalowski was actually to have little direct influence on the Polish Peasant Party, which Wyslouch finally succeeded in forming in 1895 with the object of organising the peasantry as a political force independent of the existing parties. At first, owing to the undemocratic character of the electoral laws, the new party was able to elect only a handful of members to the provincial diet in Lwow and to the central parliament in Vienna. But from 1907 onwards, with the introduction of universal suffrage for the latter, the party's influence increased until, just before 1914, it was already the largest Polish group at Vienna.

The party's programme was by no means revolutionary. Its main object was to gain political equality for the peasants within the framework of a parliamentary regime. In general it stood for the interests of the peasant smallholder, whose ownership of his plot of land helped to make him independent of landlord or government official. But, on the economic side, its programme was marked by a lack of depth. Most of its economic demands referred to the minor everyday grievances of the peasant; there was no attempt to advocate a radical transformation of society. An important place, especially in the party's educational activities, was given to the task of making the peasants, at first only dimly conscious of their Polish nationality, aware of their national heritage, from which they had for centuries been excluded. The Peasant Party in its early years was essentially a national party, though in no sense chauvinistic. It made common cause, for instance, with the Ukrainian peasants who formed a majority of the population in East Galicia.

The first two decades of the party's existence were to see its gradual liberation from the tutelage of middle-class radical intellectuals and 
the passing of effective control into the hands of peasant-born leaders. The party had never been able to work at all closely with the small Galician Social Democratic Party; and the cessation, from about 1905 , of the fierce hostility of the clergy, and the conclusion in 1908 for opportunistic reasons of an electoral alliance with the ruling Conservative Party, signified a marked toning down of the party's earlier political and social radicalism.

In 1913 a split occurred in the party, due in large measure to dissatisfaction with the conduct of the party leader, Jan Stapinski, who was now to veer from close collaboration with the Conservatives to a renewed radicalism. Though at first forces looked fairly equally divided, the more socially moderate section under Witos, which took on the name Piast after Poland's first dynasty of peasant origin, was alone able to gather substantial support after 1918.

When in that year Poland regained its independence, apart from the existence of a strong, conservatively inclined peasant party in Galicia, a second element now entered into the main stream of the Polish Peasant Movement. This was the group of so-called Congress Kingdom populists, which had been working, more as educationalists than as politicians, among the peasants in the Congress Kingdom, as the main Polish province previously administered by Russia was called. ${ }^{1}$

Agrarian socialist ideas, according to which the peasantry, not the industrial workers, were looked upon as the basis of a new social order, had spread to the Congress Kingdom from Russia in the 1880 s. A journal called the Voice (Glos) had been founded in Warsaw in 1886 as a mouthpiece of such views. But, before it was closed down by the Russian authorities eight years later, its editor and his nearest collaborators had already transferred their political allegiance to the National Democratic camp which was forming. This group was soon to become socially conservative though it always, indeed, put much stress on winning the Polish peasant for nationalism.

The real peasant movement in the Congress Kingdom did not begin until about 1905, at the time of the outbreak of revolution in the Russian Empire. It was founded by socialists who considered that more attention should be devoted to the peasantry than was in fact done in the official socialist party programme. These early populists, however, despite their disagreement with some aspects of the Socialist Party's

1 For the political Peasant Movement in Galicia, see the introduction and bibliography in Krzysztof Dunin-Wasowicz, Czasopismiennictwo Ludowe w Galicji (Wroclaw, I95 2), and the references in my articles in the Slavonic and East European Review (London), December I951, and the Journal of Central European Affairs (Colorado), October 1954. There are no general studies of either Congress Kingdom populism or the inter-war peasant parties, which contain adequate bibliographical details. 
policy, were prepared to work in close co-operation with it. They derived mainly from the intelligentsia - schoolteachers, journalists and engineers. At the same time, however, some of the most enlightened and best educated peasants also began to take part in the movement.

The development of Congress Kingdom populism may well be divided into three stages. First came the foundation, at the end of I 904, of a short-lived and numerically insignificant organisation called the Polish Populist Union. Its leadership came almost entirely from intellectuals. It aimed, in theory, at a radical transformation of the existing social order into "a co-operative commonwealth". The Union's object, in the words of its published programme, which was worked out by the famous libertarian socialist, Edward Abramowski, was to be:

"The widest possible amalgamation of peasant holdings into great co-operative enterprises, in other words, a free federative collectivism, based not upon compulsory expropriation and the nationalisation of the land, but upon the voluntary, gradual amalgamation of private holdings, with the aim of organising co-operative buying, selling and production." 1

In May 1907, after barely two years of open activity, the Union was closed down by the Russian authorities. In November of the same year, however, with the founding of a paper called the Dawn (Zaranie), Congress Kingdom Populism entered its second stage. The Dawn took as its slogan the words: "The peasants for themselves". Under its talented editor, Maximilian Malinowski ${ }^{2}$, it attempted above all to raise the peasant's educational level by the improvement of his methods of agricultural production, by the organisation of selfhelp organisations in the villages, by the setting up of small agricultural schools and short courses for the peasants, and in general by the dissemination of knowledge on various subjects through the pages of the Dawn. The paper continued to advocate the co-operative ideal in peasant production, which it had inherited from the Polish Populist Union. While not sharing the Galician populists' suspicious attitude towards the Socialist Party, the Dawn was equally nationalist in outlook.

The final stage in the movement's evolution, that of the setting up of a political organisation for the peasantry, did not come until after the outbreak of the First World War, when, with the withdrawal of the Russian armies in 1915 , the Poles in the Congress Kingdom at last

1 Henryk Syska, Przez walke do zwyciestwa (Warsaw, 1949), p. 56.

2 His memoirs, written in extreme old age and published under the title Chlopski Ruch Zaraniarski w Bylej Kongresowce przed pierwsza wojna swiatowa (Warsaw, 1947), are of considerable interest, though chaotically put together. 
obtained under the ensuing Austro-German occupation a limited freedom of political activity. At the end of the same year, therefore, three small groups, which had been carrying on activity, mainly of an educational nature, among the peasantry, joined together to form a political Peasant Party. The new party drew its main support from the followers which the editor of the Dawn had been gathering around his paper, until its suppression by the Tsarist authorities early in 1915 . While its leadership was still largely taken from the intelligentsia, an increasing number of the peasantry was coming to the fore. At the beginning of 1918 this Congress Kingdom Peasant Party took on the name Liberation (Wyzwolenie) from the title of the party organ to distinguish itself from the Galician peasant parties, and it is by this name that it was to figure prominently during the interwar years in the political life of the independent Polish state.

Politically, the history of Poland between the two wars may be divided into two periods. The first period lasted until May 1926 when Pilsudski's coup d'état put an end to the liberal parliamentary regime, which, its bewildering kaleidoscope of short-lived governments and conflicting political parties, was indeed, as both left and right agreed, in urgent need of reform. Henceforth, until the outbreak of war in September 1939, Poland moved in the direction of a dictatorship. Nevertheless, opposition parties - with the exception of the Communists - continued to exist till the end, though they were hindered in action and cut off from any influence on government.

Economically, the inter-war years were marked by the continuing poverty of the peasantry. There was a large rural proletariat as well as a semi-proletariat of smallholders, who held over half the total number of peasant holdings. A number of reasons contributed to this state of affairs. There was, first, the destruction of the years of war, which continued for Poland until the middle of 1921 , and later came the years of the world depression. In the second place, there was the inheritance from the past when Poland's economic development had sometimes been consciously retarded in the interests of the partitioning powers. A large amount of land still remained in the hands of the big estates. But, even if land reform had been more radical and faster than in fact it was - with important exceptions the laws covered estates over I 80 hectares - it would have proved only a temporary expedient. The causes of rural poverty went deeper. They lay, above all, in the dwindling of rural holdings due to the very high birth-rate as well as to the fact that the country was without proper outlet for its surplus population. Poland was underdeveloped industrially, and the previous emigration to the United States and to Germany was no longer possible on anything like the same scale as before the war. 
There was, therefore, a disguised unemployment of over a quarter of the rural population. In addition, the price-scissors between agricultural and industrial products was a marked feature of the 'thirties, and the heavy burden of taxation was particularly onerous for the almost self-sufficient small peasant, who often had to go short himself in order to obtain money with which to pay his taxes. 1

It was, therefore, against a background of internal instability, economic distress and an increasingly threatening international situation that the Polish Peasant Movement developed between the wars. For the first twelve years of independence, despite several attempts to achieve peasant unity, the movement was split into at least two major peasant parties. In I93 I, however, the separate peasant parties merged into one united party.

The main feature of the early period, then, was this division of the movement into a number of separate and competing parties. In each diet there were always three or four such parties. But the main division, throughout, remained the split between the socially conservative Piast and the radical Liberation Party. Though the situation fluctuated from year to year the balance between left and right in the movement was roughly equal, though the Liberation Party was, on the whole, weaker than Piast.

This division was primarily a legacy from the years of partition. Piast continued to find its chief support in the former Austrian parts of Poland; while, even as late as I930, the overwhelming majority of deputies from the Liberation party was elected in constituencies situated in the former Congress Kingdom. The split did not result, therefore, as some writers have attempted to prove, from a division between rich and poor peasants, since it was just in some of the most poverty-stricken areas of Poland that the more conservative Piast had its main support. Indeed the words of the first leader of the Liberation Party, Stanislaw Thugutt, a man of middle-class origins but a radical in his political views, are an apt commentary on this situation. He writes in his Autobiography: "Nowhere as much as in politics is the question so vital as to whether someone began his political activity under the Russians or under the Austrians, that is to say, whether in the tradition of the insurrectionary struggles and undergound conspiratorial work or in an atmosphere of petty skirmishes for the attainment of very secondary ends." 2

But the division naturally was not only a matter of differing territorial origins, of divergent backgrounds - it was also a question of opposing political principles and tactics. Was the Peasant Movement,

1 See Ferdynand Zweig, Poland between the Two Wars (London, 1944), pp. 1 24-30.

2 Stanislaw Thugutt, Wybor Pism i Autobiografia (Glasgow, I943), p. I09. 
which was never to gain enough seats in parliament to form a government by itself, to seek its allies on the right or the left?

The Liberation Party, having been founded by socialist minded intellectuals - many of them ardent supporters of the policies of Pilsudski, himself a former socialist, though later an advocate of authoritarian government - and with a tradition of collaboration with the Polish Socialist Party, saw its natural allies on the left. Moreover, growing up in the struggle with Tsarism, it was strongly opposed to the right-wing National Democrats, who had been proRussian before the war. Piast, on the other hand, born in Galician conditions, regarded the National Democrats to some extent as fellow-workers in awakening the national consciousness of the peasantry. Witos had made it a condition of his entering the left-wing People's Government, set up in Lublin in November 19x8, that it should be broadened by the inclusion of the right. When this was refused he withdrew his collaboration. In addition, through fusion during the early 'twenties with right-wing peasant groups, especially in the West of Poland where, under Prussia, the peasants were both more prosperous and more conservative than in the rest of Poland, Piast acquired a right-wing which, influential within the party, was nearer in spirit to the National Democratic camp than to its fellow populists of the Liberation Party. Piast, throughout, was to stress the rights - and duties - of private peasant ownership rather than the peasant co-operativism of the Liberation Party.

Thus it came about that, during most of the 'twenties, the Polish Peasant Government was not merely split into two conflicting parties - these two parties belonged to opposing parliamentary blocks. With the Polish Socialist Party the Liberation Party formed the core of the Left Block which, after the fall of the People's Government at the beginning of 1919, was excluded from power for the greater part of the period of parliamentary government. Until the middle of 1923 Piast had formed the chief party in a Centre Block. But in April of that year it concluded an alliance with the right known to history as the Lanckorona Pact; and, as a result, a Centre-Right coalition came to power. Piast's original idea had been a broad coalition of all Polish political parties with the exception of the extreme left, but, owing to deep-seated antagonisms, the moderate left was unwilling to work with the right.

The fundamental reason for Witos's choosing, in these circumstances, to ally with the right rather than the left seems, apart from his suspicions of socialism and socialists, to have lain in his desire to see the formation of a majority government capable of carrying out land reform by way of compromise without endangering the stability of 
the state. A Centre-Left coalition would have been dependent on the vote of the national minorities and would have aroused the violent antagonism of the landowning class. This Witos was anxious to avoid even at the cost of considerable sacrifices. But the Centre-Right government in which Piast remained the junior partner, proved unable to cope with the increasing difficulties in which the young Polish state was becoming involved. In addition, its formation further inflamed the already bad relations between the two peasant parties and destroyed the possibility of a united peasant movement for a number of years to come.

Both peasant parties were, indeed, united on one point: their wish to put into effect the Land Reform Acts, which had been passed in 1919/20, largely as a result of pressure from the peasant parties. ${ }^{1}$ But they were divided once again in their attitude towards the practical implementation of these reforms. Witos summed up his attitude as follows: "I do not want stealing but the lawful acquirement of land.... That is the principle on which to create a free citizenry with a respect for the law." 2

Piast, therefore, stood for compensation for those landowners whose estates were to be divided up. Witos, with his belief that the peasant was the backbone of the nation, preserving the national traditions and culture in purer form than the other sections of the community, saw. in the Polish peasantry an element which would strengthen the stability and Polishness of the new state. Land reform, in his view, was not to cause division within the Polish community and internal unrest. In a speech in the diet in I919 he said: "If today we put forward the demand that the land should be given over into the hands of those who work it and who have preserved it for Poland, we do so, above all, because we believe that it will thus be won for the Fatherland." 3 The Liberation Party, on the other hand, although at first it advocated a small sum as compensation for the estates divided up as a result of land reform, in March 1925 passed a resolution at its party congress demanding confiscation without compensation. This became a further source of conflict between Piast and the Liberation Party.

An important difference between the two peasant parties lay in the social origins of their leaders. In Piast the peasant element was strong. This was symbolised, above all, in the figure of Witos, who preserved the peasant way of life to his death. It is related that, when not occupied with his parliamentary duties, he would return to his small

1 For land reform during the inter-war years, see Zweig, op. cit., pp. 131-34.

2 Stefan Kora, Witos a Panstwo Polskie (Lwow, 1936), p. 62.

3 Wincenty Witos, Wybor Pism i Mow (Lwow, 1939), p. 126. 
farm in South Poland to pursue the life of a working peasant. ${ }^{1}$ Cautious, suspicious and with a strong dose of peasant cunning, but at the same time wholeheartedly devoted to the interests both of his class and of his country, a sincere democrat and a skilful parliamentarian, Witos succeeded, as no one else in Poland, in winning the allegiance of the peasant masses. Moreover, unlike some of the other peasant leaders, he was not afraid of power, and indeed his lifelong object was to win for Poland's peasant majority its proper influence in the state.

The leaders of the Liberation Party, on the other hand, were mostly men of middle class origin, drawn to the peasant cause rather by political idealism than by practical experience of the peasant's life. During the 'twenties the party tended to become more and more a radical bourgeois liberal party, with strongly marked anti-clerical tendencies, rather than a strictly peasant party. In 1925 a considerable section of the party, wishing to emphasise the peasant character of the movement, split away on this issue to form a separate party (Stronnictwo Chlopskie). But even in Piast, which never ceased to be essentially a peasant party, the percentage of middle-class intellectuals who occupied key positions within the party increased during the interwar years:

During the years of parliamentary government, indeed, the peasant parties, taken as a whole, never succeeded in winning a majority of the votes, although the peasantry then formed over half the total population of the country. This was due, first, to the fact that the National Democrats, especially in the Western provinces, had very considerable support among the peasantry. Secondly, the socialists were to gain an increasing following among the rural proletariat. In addition, the national minorities had their own parties; and in the Eastern borderlands the Communists had a following among the White Ruthenian peasantry. But the political Peasant Movement probably had the support of a good majority of the Polish peasantry.

Though Piast exercised a considerable influence on state policy until the fall of the Centre-Right coalition government at the end of 1923 - Witos had also been Prime Minister in the Government of National Defence during the Russo-Polish War of 1920 - the peasant parties were only in power, and then only as junior partners in coalition governments, for just over two and a half out of the seven and a half years of constitutional government. The Liberation Party was in opposition almost the whole time, and Piast had only held power through compromise with the parties of the right. Governments before the coup d'état of 1926, of which there were as many as fourteen, were usually either centre-right coalitions or cabinets of non-party experts. After 1926 the peasants were totally excluded from 1 Kora, op. cit., p. 2. 
political power, and the rate of land reform slowed down as a result of pressure from the landowners.

During the late 'twenties the peasant parties were in many ways at their lowest ebb. But, especially among the rank and file members, the feeling was growing increasingly strong that, in face of the threat to all political parties from the Pilsudski regime, which went so far as to imprison a number of its leading opponents in 1930 in the fortress of Brest Litovsk, unity was essential for the very existence of the movement. A new generation of young peasant activists, too, was growing up, untrammelled by the separate traditions of life under the three partitioning powers. In March I93 I, therefore, the three main peasant parties - Piast on the right and the Liberation Party and its offshoot, the Peasants' Party (Stronnictwo Chlopskie), on the left - finally agreed to merge into one united Peasant Party.

In the history of the Polish Peasant Movement the 'thirties were marked, first, by increasing radicalism as a result of the political opposition to the government. The united Peasant Party stood for a return to a strengthened and reformed parliamentary democracy and for a reversal of the trend towards an authoritarian regime. The party's radicalism, however, was not confined to political matters alone, but was felt, too, in its economic demands. In 1935, for instance, though with an influential minority dissenting, it accepted the Liberation Party's principle of the expropriation of the large estates without compensation for their owners. Old ideas of organising producers' co-operatives in agriculture, such as had been prevalent among the more revolutionary of the Congress Kingdom populists, were revived.

During this period Witos, who had been one of the opposition leaders arrested and imprisoned in 1930, went into exile in Czechoslovakia, returning only in 1939 after the occupation of Prague by the Germans. Meanwhile, at home attempts were being made, both before the creation of a united party and after, to form a wide antiGovernment front together with the small democratic groups on the right and with the socialists on the left. But these efforts were not altogether successful.

From 193 I onwards the Peasant Party had expressed its opposition to the government by great demonstrations of peasants, especially during the Whitsun holidays, which were now set aside as a peasant festival on the same lines as the first of May for the workers. The party also organised a series of peasant strikes, which form an almost unique phenomenon in recent European history. During these strikes, which were a form of boycott, the peasants refrained both from marketing their produce and from buying in the towns. Although economic slogans were also used, the main object of these strikes was political: 
to make the peasants' influence felt again in the state. Beginning in I932, they reached a climax in August 1937 when they were suppressed by the government with considerable violence after clashes between peasants and police. Although unsuccessful in the short run, these strikes and demonstrations showed that the united Peasant Party was now a strong mass organisation with deep roots in the peasantry. The simultaneous efforts of the government to win over the peasants were largely a failure.

A second feature of the Peasant Movement during the 'thirties was the attempt, especially on the part of the influential peasant youth movement - known by the name of Wici - to work out a new populist philosophy. In the previous decade the divided peasant parties had been singularly lacking in creative ideas. They had become absorbed in the day-to-day business of politics and had given little serious thought to the deeper problems of society, which would continue to exist even after the completion of land reform.

The new theories now being propounded by the young peasant politicians were still, to some extent, vague and uncrystallised, still in the experimental stage. They were radical in content and opposed both to capitalist liberalism and to Marxian socialism. In Polish they are usually known under the name Agraryzm. But this name is not altogether satisfactory, since it gives rise to confusion both with the ideas of the conservative agrarian groups of Western Europe and, more particularly, with those of the Czech Agrarian Party, with which Polish Agraryzm had little in common.

Its main points, as set out by the youth movement in 1934 and in somewhat modified form incorporated into the Peasant Party's new programme in the following year, represented a combination - and an amplification - of the ideology of Piast and the Liberation Party. The basis of the agrarian structure was still to be the independent farm, worked by the peasant and his family. The cooperative movement, however, was to be developed so as to form the foundation of a new social order, and cooperatives were gradually to replace the middleman between peasant and consumer. In regard to industry, wrote one of the leading exponents of Agraryzm, Stanislaw Milkowski, the Peasant Movement should "accept the socialist solution of the problem". Mines and the banking system were likewise to be socialised on the principle of expropriation without compensation; though this view was not representative perhaps of the main body of opinion in the party. "The peasantry marches in solidarity with the whole world of labour, and in particular with the working class organised on principles similar to those of Agraryzm." Naturally this peasant radicalism 
was not very acceptable to many of the more conservative members of the movement. 1

At the outbreak of the Second World War the Polish Peasant Movement was united in one party enjoying strong support among the peasant masses and with a considerable following among members of the intelligentsia, especially those of peasant origin. The party, and especially its youth movement, was radical, if not revolutionary in spirit - largely as a result of the political opposition to the government and to the continued poverty of the peasantry. Serious attempts were being made to strengthen the weakest link in the peasant programme: the movement's previous inability to come to grips with the problem of rural overpopulation, to see beyond land reform to a more comprehensive solution of the deepseated maladies of contemporary society. Including both a right and a left wing, and even a small extreme left group of young intellectuals under communist influence, and embracing well-to-do farmers as well as povertystricken owners of dwarf holdings and agricultural labourers, whose interests in the past had often pulled in opposite directions, the united Peasant Party had come, nevertheless, to accept collaboration with the industrial workers as a theoretical necessity, though it had so far been unable to achieve it in practice. The party in its ideology stood half-way between capitalist liberalism and democratic socialism, accepting ideas from each camp and attempting to achieve a new and original synthesis, based on the private ownership of the working peasant within the framework of a cooperative economic system and a liberal parliamentary democracy.

During the German occupation all open political activities were impossible. The Peasant Party, however, took a prominent part in the work of the Polish Government - in - Exile in London; and its leader, Mr Mikolajczyk, was to succeed General Sikorski as Prime Minister in 1943. The party also collaborated in the underground Polish state which carried on the work of resistance in the home country, and its peasant battalions formed part of the Home Army.

At the end of the war in 1945, contrary to the opinion of many of the Polish émigrés but undoubtedly in accordance with the wishes of the Peasant Party in Poland, as well as of very many others unconnected with the movement, Mr Mikolajczyk decided to return to Poland to work there under the conditions created by the Yalta and Moscow agreements. For nearly two and a half years the Peasant Party under his leadership was permitted to function, though increasingly harassed by the Communists, who exercised control over most of the organs of power.

1 Tadeusz Rek, Ruch Ludowy w Polsce, vol. III (Warsaw, 1947), pp. I I6-20. 
While the war was still on, a rival Peasant Party had been set up under communist auspices, but with the support of certain genuine leftwing populists, who were mostly, however, either soon to leave the party or to be removed over the next few years from positions of trust within it. The inner leadership was held by former members of a small fellow-travelling peasant party, the so-called Independent Peasant Party, which had been suppressed in the late 'twenties. On his return to Poland Mr Mikolajczyk had been able to re-establish his own separate organisation, independent of communist control, though several attempts were made to infiltrate it or to win over prominent party members. At the same time rightwing elements, foreign to the aims and ideals of the Peasant Movement, gave their support to Mr Mikolajczyk's party, due to the fact that the old parties of the right were not allowed to function legally. This provided a convenient excuse to brand the genuine Peasant Party as reactionary; and the party had, in fact, shifted towards the right in comparison with its position in the 'thirties.

At first Mr Mikolajczyk held the office of Vice-Premier, but after the decidedly undemocratic elections of January 1947, in which his Peasant Party stood in opposition to the government block and was decisively defeated, he resigned; and in October he went into exile for a second time. Thereafter, only an emasculated party was allowed, and this fused in 1949 with the government Peasant Party. The United Peasant Party thus formed has continued to exist only as an annexe of the Communist Party. ${ }^{1}$

Today in Poland the peasant has once again been forced from power and influence in the state. The independent Peasant Movement functions only in exile. Nevertheless, even after the intensive industrialisation of the last few years, almost half the country's inhabitants still live in the villages. ${ }^{2}$ The Polish peasant, 'therefore, remains a positive factor of the greatest importance not only in the political and social life of his own land, but also for the future development of the whole of Central and Eastern Europe.

1 Almost every book or article dealing with the political situation in Poland during the war and immediate post-war years at least touches upon the position of the Peasant Party. Mr. Mikolajczyk has given his account of events in The Pattern of Soviet Domination (London, 1948).

2 The Polish Countryside in Figures (Warsaw, 1954), p. 22. Cf. Bulletin of the International Peasant Union (New York), July - August, r954, p. 4, which gives the figure as "about so percent". 